\title{
PENYELESAIAN PERKARA PIDANA DENGAN KONSEP KEADILAN \\ RESTORATIF (RESTORATIVE JUSTICE) DALAM SISTEM \\ PERADILAN PIDANA TERPADU DI INDONESIA
}

\author{
Kristian \& Christine Tanuwijaya \\ Dosen di Universitas Kristen Maranatha (UKM) \& Mahasiswa Fakultas \\ Hukum Universitas Kristen Maranatha
}

\begin{abstract}
ABSTRAK
Metode penyelesaian masalah yang dapat ditempuh pada dasarnya terbagi menjadi dua yaitu penyelesaian dengan jalur litigasi dan non litigasi.Dalam kenyataannya, apabila terjadi suatu permasalahan khususnya yang berkaitan dengan hukum pidana (perkara pidana), model penyelesaian masalah selalu dilakukan dengan menggunakan jalur litigasi. Penyelesaian perkara dengan menggunakan jalur litigasi ini dalam prakteknya tidak selalu berjalan sesuai dengan apa yang diharapkan karena penyelesaian perkara dengan menggunakan jalur litigasi dalam sistem peradilan pidana tradisional saat ini justru menimbulkan permasalahanpermasalahan baru misalnya: pola pemidanaan yang masih bersifat pembalasan, menimbulkan penumpukan perkara, tidak memperhatikan hak-hak korban, tidak sesuai dengan asas peradilan sederhana; proses panjang, rumit dan mahal, penyelesaian bersifat legistis dan kaku, tidak memulihkan dampak kejahatan, kondisi lembaga pemasyarakatan yang tidak memadai, tidak mencerminkan keadilan bagi masyarakat dan lain sebagainya padahal, hukum dibuat pada hakikatnya untuk memberikan keadilan dan manfaat bagi manusia. Melihat berbagai fenomena ini, dalam perkembangan terkini muncul sebuah konsep baru yakni konsep keadilan restoratif.Konsep atau pendekatan keadilan restoratif dinilai dapat mengatasi berbagai permasalahan dalam sistem peradilan pidana tradisional sebagaimana disebutkan diatas.Penelitian ini akan membahas mengenai penerapan keadilan restoratif (restorative justice) dalam sistem peradilan pidana terpadu di Indonesia. Penelitian ini merupakan penelitian hukum normatif yang bersifat deskriptif analitis.Pendekatan yang digunakan adalah pendekatan perundang-undangan, pendekatan konseptual dan pendekatan asasasas hukum.
\end{abstract}

Kata Kunci: Keadilan Restoratif, Sistem Peradilan Pidana Terpadu.

\begin{abstract}
Various problems that occur in a community, is a social phenomenon that has existed since the start of human life. Problem solving methods that can be taken is basically divided into two, namely the completion of the litigation and nonlitigation pathway. In fact, if there is a problem, especially with regard to criminal law (criminal case), the model of problem solving is always done using the path of litigation. The settlement of this litigation by using paths in practice does not always go according to what is expected due to the settlement of
\end{abstract}


litigation by using the path in the traditional criminal justice system today would lead to new problems such as: pattern of retaliatory punishment still, causing a buildup of the case, do not pay attention to the rights of the victim, not in accordance with the principle of simple justice; process is long, complicated and expensive, and the settlement is legistis stiff, does not restore the effects of crime, prisons conditions are not adequate, does not reflect justice for the community and so although, the law was made essentially to provide fairness and benefits to humans. Looking at these phenomena, in the latest development emerged a new concept or approach the concept of restorative justice. The concept of restorative justice approaches assessed or can cope with various problems in the traditional criminal justice system as mentioned above.This study will discuss the application of restorative justice in terms of the integrated criminal justice system in Indonesia. This research is a descriptive normative legal analysis. The approach used is a statutory approach, conceptual approach, and the principles of law.

Keywords: Restorative Justice, Integrated Criminal Justice System.

\section{PENDAHULUAN.}

Dewasa ini, apabila terjadi suatu tindak pidana, masyarakat cenderung menggunakan jalur pengadilan yang secara konseptual dan teoritis akanmenciptakan keadilan, namun dalam kenyataannya hal ini merupakan hal yang tidak mudah untuk dicapai.Perlu disadari bahwa hasil yang akan dicapai dari proses penyelesaian perkara dengan jalur peradilan bersifat win lose solution, dengan sifat yang demikian, akan terdapat pihak yang menang dan terdapat pula pihak yang kalah. Dengan kenyataan seperti ini, penyelesaian suatu perkara melalui jalur peradilan tradisional pada umumnya kerap menimbulkan satu rasa "tidak enak", menyimpan dendam, merasa tidak puas, merasa tidak adil bahkan lebih parah berniat ingin membalas dendam.

Hal-hal ini akan tertanam kuat di benak pihak yang kalah sehingga ia akan berupaya untuk mencari "keadilan" ke tingkat peradilan lebih lanjut (baik melakukan banding maupun melakukan kasasi bagi pihak yang tidak puas dengan putusan pengadilan tinggi). Dengan adanya fenomena ini, tentunya telah menyebabkan arus perkara yang mengalir melalui pengadilan (baik itu dalam tingkat Pengadilan Negeri, Pengadilan Tinggi maupun pada tingkat Mahkamah Agung) melaju dengan sangat cepat sehingga terjadi penumpukan perkara. 
Melihat fenomena tersebut, benarlah apa yang dikemukakan oleh Joni Emirzon dalam bukunya yang berjudul Alternatif Penyelesaian Sengketa di Luar Pengadilan, bahwa hal ini pada umumnya dapat dikategorikan sebagai salah satu kelemahan bagi suatu lembaga litigasi yang tidak dapat dihindari walaupun sudah menjadi suatu ketentuan. ${ }^{1}$

Pernyataan serupa dikemukakan oleh Satjipto Raharjoyang menyatakan bahwa penyelesaian perkara melalui sistem peradilan yang berujung pada vonis pengadilan merupakan suatu penegakan hukum (law enforcement) ke arah jalur lambat. Hal ini karena penegakan hukum itu melalui jarak tempuh yang panjang, melalui berbagai tingkatan mulai dari Kepolisian, Kejaksaan, Pengadilan Negeri, Pengadilan Tinggi bahkan sampai ke Mahkamah Agung. Pada akhirnya berdampak pada penumpukan perkara yang jumlahnya tidak sedikit di pengadilan. ${ }^{2}$ Selain itu, keadilan yang diharapkan melalui jalan formal ternyata belum tentu mencerminkan rasa keadilan, mahal, berkepanjangan, melelahkan dan tidak menyelesaikan masalah serta yang lebih parah lagi adalah di dalamnya penuh dengan praktek korupsi, kolusi dan nepotisme. ${ }^{3}$

Di samping menimbulkan penumpukan perkara, dalam banyak kasus yang terjadi, khususnya yang terjadi di Indonesia, misalnya kasus pencurian sandal jepit yang menimpa AAL, kasus pencurian piring yang menimpa Rasminah, kasus pencurian kakao yang senilai Rp. 2.500,00 yang menimpa Aminah,serta beberapa kasus lainnya yang sejenis tidak seharusnya dituntut dan masuk ke pengadilan. Dikatakan demikian karena putusan hakim dalam kasus-kasus tersebut dan kasus-

1 Joni Emirzon, Alternatif Penyelesaian Sengketa di Luar Pengadilan, Jakarta, PT Gramedia Pustaka Utama, 2001, hlm. 3-5.

2 Satjipto Rahardjo, Sisi-Sisi Lain dari Hukum di Indonesia, Jakarta: Kompas, 2003, hlm.170.

3 R. Budi Wicaksono, Community Policing dan Restorative Justice Sebagai Paradigma Baru dalam Resolusi Konflik, Tesis Fakultas IImu Sosial dan Ilmu Polilik Departemen Kriminologi Program Pasca Sarjana Universitas Indonesia. Depok, 2008.hlm.47.Lebih lanjut, dapat dilihat bahwa pengadilan sebagai tempat masyarakat berharap; tempat di mana keadilan dapat terwujud.Dalam kenyataannya saat ini, pengadilan berubah menjadi pasar yang memperdagangkan putusan pengadilan.Padahal, tujuan dari hukum itu sendiri adalah untuk keadilan dan menciptakan ketertiban dan juga keseimbangan dalam masyarakat. Lihat selengkapnya dalam: Sudikno Mertokusumo, Mengenal Hukum: Suatu Pengantar, Universitas Atmajaya, Yogyakarta 2010., hlm. 99-100. 
kasus lain sejenis banyak dikecam publik karena dinilai tidak memenuhi rasa keadilan.

Hal ini diperparah dengan peran dan fungsi peradilan tradisional yang dianggap sudah tidak berfungsi sebagaimana mestinya. Mengutip pernyataan dari Bambang Sutiyoso dalam bukunya yang berjudul "Penyelesaian Sengketa Bisnis, Solusi Dan Antisipasi Bagi Peminat Bisnis Dalam Menghadapi Sengketa Kini dan Mendatang" menyatakan bahwa: Dewasa ini penyelesaian sengketa melalui pengadilan mendapat kritik yang cukup tajam, baik dari kalangan praktisi maupun teoritisi hukum. Peran dan fungsi peradilan dewasa ini dianggap mengalami beban yang terlampau padat (overloaded), lamban dan buang waktu (wasteof time), biaya mahal (veryexpensive) dan kurang tanggap terhadap kepentingan umum, atau dianggap terlampau formalitik (formalistic) dan terlampau teknis (technically), terlebih adanya "mafia peradilan" yang seakan-akan mengindikasikan keputusan hakim dapat dibeli. ${ }^{4}$

Menanggapi berbagai persoalan diatas, dalam perkembangan terkini muncul sebuah alternatif yang ditawarkan yakni dengan melaksanakan konsep keadilan restoratif (restorative justice).Konsep keadilan restoratif (restorative justice) adalah alternatif yang populer di berbagai belahan dunia untuk penanganan perbuatan melawan hukum (melawan hukum dalam arti formal) karena menawarkan solusi yang komprehenif dan efektif. ${ }^{5}$ Keadilan restoratif (restorative justice) bertujuan untuk memberdayakan para korban, pelaku, keluarga dan masyarakat untuk memperbaiki suatu perbuatan melawan hukum dengan menggunakan kesadaran dan keinsyafan sebagai landasan untuk memperbaiki kehidupan bermasyarakat. ${ }^{6}$

4 Bambang Sutiyoso, Penyelesaian Sengketa Bisnis, Solusi Dan Antisipasi Bagi Peminat Bisnis Dalam Menghadapi Sengketa Kini dan Mendatang, Yogyakarta, Citra Media, 2006, hlm. 30.

5 Gordon Bazemore dan Mara Schiff, Juvenile Justice Reform and Restorative justice: Building Theory and Policy from Practice, Willan Publishing, Oregon, 2005, hlm.5. Dikutip juga oleh Dewi DS dan A. Syukur Fatahilah, Mediasi Penal: Penerapan Restorative Justice di Pengadilan Anak Indonesia, Depok, Indie Publishing, 2011, hlm. 4.

6 Geoge pavlich, Towards an Ethics of Restorative Justice, dalam Restorative Justice and The Law, ed Walgrave, L., WWillan Publishing, Oregon, 2002, hlm. 1. Di kutip juga oleh: Dewi DS dan A. Syukur Fatahilah, Ibid. 
Dari latar belakang masalah tersebut diatas, maka Penulis mengidentifikasi 2 (dua) permasalahan yaitu sebagai berikut:

1. Bagaimana implementasi konsep keadilan restoratif (restorative justice) dalam sistem peradilan pidana terpadu di Indonesia?

2. Apakah sistem peradilan pidana terpadu di Indonesia telah mengadopsi konsep keadilan restoratif (restorative justice)?

\section{PEMBAHASAN.}

\section{A. Definisi Keadilan Restoratif.}

Konsep keadilan restoratif atau keadilan pemulihan (restorative justice) merupakan suatu model pendekatan baru dalam upaya penyelesaian perkara pidana. Berbeda dengan sistem yang ada sekarang (sistem pidana tradisional), pendekatan atau konsep keadilan restoratif atau keadilan pemulihan (restorative justice) lebih menitikberatkan pada adanya partisipasi langsung dari pelaku, korban dan masyarakat dalam proses penyelesaian perkara pidana. Oleh karena itu, pendekatan ini populer disebut juga dengan istilah "non state justice system" di mana peran Negara dalam penyelesaian perkara pidana menjadi kecil atau bahkan tidak ada sama sekali. Namun demikian, kehadiran pendekatan atau konsep keadilan restoratif atau keadilan pemulihan (restorative justice) banyak diwarnai berbagai pertanyaan baik secara teoritis maupun secara praktis. ${ }^{7}$

Permasalahan utama untuk memberlakukan atau mengimplementasikan pendekatan atau konsep keadilan restoratif (restorative justice) dalam sebuah sistem hukum pada umumnya dan pada sistem peradilan pidana pada khsusunya terletak pada mekanisme penyelesaian yang ditawarkan oleh pendekatan atau konsep keadilan restoratif (restorative justice) berbeda dengan mekanisme penyelesaian yang ditawarkan oleh sistem peradilan pidana yang ada saat ini sehingga masih sulit untuk diterima. Hal ini dikarenakan mekanisme yang ditawarkan oleh pendekatan atau konsep keadilan restoratif (restorative justice) lebih mengedepankan konsep perdamaian, konsep "mediasi" dan konsep

7 Eva Achjani Zulfa, "Restorative Justice: Alternatife Hukum". http://evacentre.blogspot.com/2009/11/restorative-justice.html diakses terakhir pada hari Senin, tanggal 09 September 2013 pada pukul 12.33. 
rekonsiliasi di mana pelaku, korban, aparat penegak hukum dan masyarakat luas berpartisipasi secara langsung dalam menyelesaikan perkara pidana tentunya berbanding terbalik atau bertentangan dengan sistem peradilan pidana tradisional yang sudah diberlakukan sejak lama dan berlaku hingga saat ini.

Hal ini dilatarbelakangi oleh fokus perhatian dan pandangan atas suatu tindak pidana dan keadilan yang dicapai atas suatu penyelesaian perkara pidana. ${ }^{8}$ Pandangan terhadap arti dari suatu tindak pidana dan pemidanaan yang dianut dalam sistem peradilan pidana tradisional saat ini adalah "is a violation of the state, defined by lawbreaking and guilty" (pelanggaran negara didefinisikan sebagai pelanggaran hukum dan bersalah). Sementara keadilan dalam sistem peradilan pidana tradisional dipahami sebagai "terbuktinya dakwaan dan penjatuhan pidana kepada pelaku oleh Negara sebagai pemegang kedaulatan dalam menjatuhkan pidana. Otoritas demikian pada akhirnya justru berimbas pada kondisi tidak terwakilinya kepentingan korban dan masyarakat dalam sebuah sistem yang berkaitan satu dengan yang lain. ${ }^{9}$

Berbeda dengan konsep keadilan restoratif (restorative justice), Tonny

MarshalldanHoward Zehrmenyatakan sebagai berikut:

\section{1) Tonny Marshall:}

"Restorative justice is a process whereby all the parties with a stake in a particular offense come together to resolve collectively how to deal with the aftermath of the offense and its implications for the future." 10

(keadilan restoratif (restorative justice) sebagai "proses yang melibatkan semua pihak yang memiliki kepentingan dalam masalah pelanggaran tertentu untuk datang bersama-sama menyelesaikan secara kolektif bagaimana menyikapi dan menyelesaikan akibat dari pelanggaran dan implikasinya untuk masa depan). ${ }^{11}$

Ibid.

Ibid.

10 Tony marshall, Keadilan restoratif: Tinjauan di London, Home Office Research Development and Statistics Directorate, 1999. Jakarta: Office Home Penelitian Pengembangan dan Statistik Direktorat, 1999., Page. 5. Lihat juga dalam: Kristian, Penyelesaian Perkara Pidana Dengan Konsep atau Pendekatan Keadilan Restoratif (Restorative Justice) Khususnya Secara Mediasi (Mediasi Penal) Dalam Sistem Hukum Pidana Indonesia Ditinjau Dari Filsafat Hukum, Jurnal Hukum Mimbar Justitia Vol. VI No. 02 Edisi Juli-Desember 2014., hlm. 460.

11 Heru Susetyo dan Tim Kerja Pengkajian Hukum, Laporan Tim Pengkajian Hukum Tentang Sistem Pembinaan Narapidana Berdasarkan Prinsip Restorative Justice, Badan Pembinaan Hukum Nasional Kementerian Hukum Dan Hak Asasi Manusia Republik Indonesia Tahun 2012., hlm. 9. Lihat juga dalam...Ibid. 


\section{2) Howard Zehr:}

"Viewed through a restorative justice lens, "crime is a violation of people and relationships. It creates obligations to make things right. Justice involves the victim, the offender, and the community in a search for solutions which promote repair, reconciliation, and reassurance."12(Dilihat melalui lensa keadilan restoratif, kejahatan adalah pelanggaran orang dan hubungan ini menciptakan kewajiban untuk melakukan hal yang benar.Keadilan melibatkan korban, pelaku dan masyarakat dalam mencari solusi yang mempromosikan perbaikan, rekonsiliasi dan jaminan).

\section{B. Sistem Peradilan Pidana (Criminal Justice Sistem).}

Muladi dalam bukunya yang berjudul "Kapita Selekta Sistem Peradilan Pidana" mengemukakan bahwa sistem peradilan pidana (criminal justice system) adalah suatu jaringan (network) peradilan yang menggunakan hukum pidana materiil, hukum pidana formil maupun hukum pelaksanaaan pidana.Namun kelembagaan ini harus dilihat dalam konteks sosial. ${ }^{13}$ Sifat yang terlalu formal jika dilandasi hanya untuk kepentingan kepastian hukum saja akan membawa bencana berupa ketidakadilan. ${ }^{14}$

Sistem peradilan pidana (criminal justice system) di Indonesia diatur secara tegas dalam Kitab Undang-Undang Hukum Acara Pidana (KUHAP) atau Undang-Undang No. 8 tahun 1981. Dikatakan demikian karena Undang-Undang No. 8 tahun 1981 atau Kitab Undang-Undang Hukum Acara Pidana (KUHAP) sebenarnya identik dengan penegakan hukum pidana yang merupakan suatu sistem kekuasaan atau kewenangan-kewenangan yang diberikan kepada negara dalam menegakkan hukum pidana yakni kepolisian, kejaksaan, hakim dan lembaga pemasyarakatan.

Pengertian sistem peradilan pidana (criminal justice system) disebut juga dengan istilah law enforcement system karena di dalamnya mengandung suatu

2 Howard Zehr, Changing Lenses: A New Focus for Crime and Justice, Scottdale, Pennsylvania; Waterloo, Ontario: Herald Press, 1990. page. 181. Lihat juga dalam: Eva Achjani Zulfa, Keadilan Restoratif dan Revitalisasi Lembaga Adat di Indonesia, Loc Cit., hlm. 188. Lihat juga dalam,...lbid.

13 Muladi, Kapita Selekta Sistem Peradilan Pidana, Semarang: Badan Penerbit UNDIP, 1996, hlm. 2.

14 Ibid. 
pemahaman, bahwa pada dasarnya apa yang dilakukan oleh lembaga-lembaga itu merupakan usaha konkrituntuk menegakkan aturan-aturan hukum abstrak. ${ }^{15}$

Terkait dengan integrated criminal justice system atau sistem peradilan pidana terpadu, Muladi dalam bukunya yang berjudul “Kapita Selekta Sistem Peradilan Pidana" menegaskan bahwa makna sistem peradilan pidana terpadu atau integrated criminal justice system merupakan suatu sinkronisasi atau keserampakan dan keselarasan, yang dapat dibedakan dalam beberapa hal berikut ini: ${ }^{16}$ 1) Sinkronisasi struktural (structural syncronization) adalah keserampakan atau keselarasan dalam rangka hubungan antar lembaga penegak hukum; 2) Sinkronisasi substantial (substansial syncronization) adalah keserampakan atau keselarasan yang bersifat vertikal dan horizontal dalam kaitannya dengan hukum positif; dan 3) Sinkronisasi kultural (cultural syncronization) adalah keselarasan dalam menghayati pandangan-pandangan, sikap-sikap dan falsafah yang secara menyeluruh mendasari jalannya sistem peradilan pidana.

Menambahkan pendapat dari Muladi diatas, penulis beranggapan bahwa antara sub-sub sistem yang terdapat dalam sistem peradilan pidana harus memiliki struktural, substansial dan kultural yang sama (struktural, substansial dan kultural dalam mengaplikasikan konsep atau pendekatan keadilan restoratif). Singkatnya, apabila salah satu dari sub sistem yang terdapat dalam sistem peradilan pidana tidak melaksanakan konsep atau pendekatan keadilan restoratif maka konsep atau pendekatan keadilan restoratif tidak dapat berjalan dengan baik.

\section{Implementasi Konsep Keadilan Restoratif (Restorative Justice) di Indonesia.}

Sebelum membahas lebih jauh mengenai pelaksanaan pendekatan atau konsep keadilan restoratif (restorative justice) di Indonesia, muncul sebuah pertanyaan, dapatkan pendekatan atau konsep keadilan restoratif (restorative justice) diterapkan di Indonesia? Terkait dengan pertanyaan ini, Braithwaite mengatakan bahwa:

15 Bryan A. Garner, Black's Law Dictionary, Edisi Delapan, West Publishing CO, Amerika Serikat, 2004, hlm. 901.

16 Muladi, Op.Cit., hlm. 1-2. 
"Indonesia is a nation with wonderful resources of intracultural restorative justice. Traditions of musayawarah (musyawarah) decision by friendly cooperation and deliberation-traverse the archipelago. Adat law at the same time allows for diversity to the point of local criminal laws being written to complement universal national laws. ${ }^{17}$

Berdasarkan pendapat Braithwaite tersebut, terlihat dengan jelas bahwa praktik-praktik penyelesaian masalah dengan pendekatan atau konsep keadilan restoratif (restorative justice) memang telah ada dalam kultur atau budaya bangsa Indonesia sebagaimana telah dilakukan di Sumatra Barat, sekalipun hal itu dilakukan oleh kalangan elit tertentu dari masyarakat. Braithwaite berkeyakinan dengan memberikan sedikit pelatihan maka tidak hanya kalangan elit saja yang dapat memfasilitasi praktik-praktik penyelesaiam masalah dengan pendekatan atau konsep keadilan restoratif namun lebih banyak orang, sekalipun demikian, upaya pendemokrasian praktik-praktik restoratif terhadap orang-orang Asia dapat berpotensi menimbulkan suatu kekeliruan. ${ }^{18}$

Implementasi atau pelaksanaan konsep keadilan restoratif (restorative justice) diberbagai negara setidaknya melewati 3 (tiga) tahap berikut ini: ${ }^{19}$

Konsep Keadilan Restoratif Dalam Sebuah Rangkaian Perkembangan.

\begin{tabular}{|c|c|c|c|}
\hline Indikator & $\begin{array}{c}\text { Bisa Menjadi } \\
\text { Restoratif }\end{array}$ & Restoratif Sebagian & Restoratif Sepenuhnya \\
\hline Keterlibatan & $\begin{array}{l}\text { Keterlibatan bukanlah } \\
\text { perhatian utama. } \\
\text { Keputusan yang dibuat } \\
\text { oleh pihak yang tidak } \\
\text { secara langsung terkena } \\
\text { dampak. Tidak ada } \\
\text { pilihan untuk dialog di } \\
\text { antara mereka yang } \\
\text { terkena dampak } \\
\text { langsung. }\end{array}$ & $\begin{array}{c}\text { Para pemangku kepentingan } \\
\text { merupakan kunci untuk } \\
\text { memberikan informasi } \\
\text { sampai tingkat yang terbatas. } \\
\text { Beberapa para pemangku } \\
\text { kepentingan memiliki } \\
\text { beberapa keputusan dan } \\
\text { masukan akan tetapi, } \\
\text { keputusan akhir dibuat atau } \\
\text { disetujui oleh sistem formal. } \\
\text { Dalam restoratif sebagian, } \\
\text { terdapat kesempatan terbatas } \\
\text { untuk dialog antara beberapa } \\
\text { para pemangku kepentingan. }\end{array}$ & $\begin{array}{c}\text { Semua pihak (mereka yang terluka } \\
\text { mereka yang dirugikan dan } \\
\text { masyarakat) } \\
\text { disediakankesempatan untuk } \\
\text { berpartisipasi, membentuk proses } \\
\text { dan membuat keputusan. Dalam } \\
\text { hal ini terdapat peluang yang jelas } \\
\text { untuk berdialog. Keputusan dibuat } \\
\text { secara konsensus oleh mereka } \\
\text { yang terkena dampak langsung. } \\
\text { Dan keputusan harus } \\
\text { dihormatidan dilaksanakan oleh } \\
\text { semua pihak. }\end{array}$ \\
\hline Pertanggungjawaban & Fokusnya adalah pada & Perhatian utama adalah & Fokus pada identifikasi, mengakui \\
\hline
\end{tabular}

17 Rufinus Hotmaulana Hutauruk, Penanggulangan Kejahatan Korporasi Melalui Pendekatan Restorative Justice Suatu Terobosan Hukum, Sinar Grafika, 2013.hlm. 109.

19 Kristian, Penerapan Keadilan Restoratif (Restorative Justice) Ditinjau Dari Teori Keadilan, Teori Kemanfaatan dan Teori Negara Hukum (Khususnya Negara Hukum Pancasila) Dalam Rangka Penyelesaian Perkara Pidana di Indonesia, Tesis, Universitas Katolik Parahyangan, 2014., hlm. 313. 


\begin{tabular}{|c|c|c|c|}
\hline & $\begin{array}{c}\text { aturan atau hukum yang } \\
\text { dilanggar dan } \\
\text { konsekuensi atas } \\
\text { perbuatannya } \\
\text { (pertanggungjawaban } \\
\text { pasif). } \\
\end{array}$ & $\begin{array}{c}\text { dengan membayar untuk } \\
\text { bahaya dan kebutuhan tetapi } \\
\text { fokus utama adalah aturan } \\
\text { atau hukum yang dilanggar } \\
\text { dan segala konsekuensi yang } \\
\text { muncul. } \\
\end{array}$ & $\begin{array}{l}\text { dan menangani bahaya, kebutuhan } \\
\text { dan penyebab yang muncul. Hal } \\
\text { ini menciptakan peluang bagi } \\
\text { pertanggungjawaban secara aktif. }\end{array}$ \\
\hline Perbaikan & $\begin{array}{l}\text { Memulihkan kerusakan } \\
\text { atau kerugian yang } \\
\text { dialami. } \\
\text { Pertanggungjawaban } \\
\text { pasif dari pelaku } \\
\text { biasanya berfokus tidak } \\
\text { untuk memulihkan. }\end{array}$ & $\begin{array}{l}\text { Beberapa upaya dilakukan } \\
\text { untuk memulihkan sebagian } \\
\text { kerugian yang sangat nyata. } \\
\text { Sering kali, bahaya dan } \\
\text { upaya untuk memulihkan } \\
\text { diberikan kepada orang lain } \\
\text { selain mereka yang secara } \\
\text { langsung terkena dampak. }\end{array}$ & $\begin{array}{c}\text { Berfokus pada memulihkan luka } \\
\text { fisik, emosional dan sosial dari } \\
\text { semua pihak yang terkena dampak } \\
\text { dan kebutuhan untuk sedapat } \\
\text { mungkin menangani semua pihak } \\
\text { yang terlibat. }\end{array}$ \\
\hline
\end{tabular}

Berdasarkan kriterium perkembangan konsep atau pendekatan keadilan restoratif (restorative justice) diatas, apabila dikaitkan dengan pengimplementasian konsep atau pendekatan keadilan restoratif (restorative justice) di Indonesia maka pengimplementasikan konsep atau pendekatan keadilan restoratif (restorative justice) di Indonesia baru berada pada tahap "bisa menjadi restoratif" atau setidaknya pada tahap "restoratif sebagian".

\section{Konsep Keadilan Restoratif Di Indonesia.}

Pelaksanaan konsep keadilan restoratif (restorative justice) di Indonesia bisa dimulai dari Mahkamah Agung (MA).Hal ini dikarenakan Mahkamah Agung (MA) merupakan lembaga negara yang melaksanakan kekuasaan kehakiman dan sebagai puncak peradilan. Hal ini diatur secara tegas dalam gamblang dalam berbagai peraturan perundang-undangan misalnya Undang-Undang Dasar Republik Indonesia Tahun 1945; Undang-Undang Nomor 48 Tahun 2009 Tentang Kekuasaan Kehakiman, Undang-Undang Nomor 14 Tahun 1985 sebagaimana telah diubah oleh Undang-Undang Nomor 5 Tahun 2004 sebagaimana telah diubah terakhir dengan Undang-Undang Nomor 3 Tahun 2009 Tentang Mahkamah Agung. Dengan demikian, mengingat bahwa Mahkamah Agung (MA) merupakan lembaga negara yang melaksanakan kekuasaan kehakiman dan sebagai puncak peradilan maka sudah seyogianya apabila Mahkamah Agung (MA) mengadopsi atau menganut dan menerapkan pendekatan atau konsep keadilan restoratif (restorative justice). Dalam hal ini, penulis menyoroti Mahkamah Agung (MA) karena Mahkamah Agung (MA) merupakan puncak 
sehingga apabila Mahkamah Agung (MA) mengadopsi atau menganut dan menerapkan konsep keadilan restoratif (restorative justice) maka peradilan yang ada dibawahnyapun akan mengadopsi, menganut dan menerapkan konsep keadilan restoratif (restorative justice). Dengan cara ini, diharapkan konsep keadilan restoratif (restorative justice) dapat diterapkan dalam seluruh sistem peradilan di Indonesia dari mulai Pengadilan Negeri-Pengadilan Tinggi dan Mahkamah Agung itu sendiri.

Selain itu, Undang-Undang Kekuasaan Kehakiman yaitu Undang-Undang Republik Indonesia Nomor 48 Tahun 2009 Tentang Kekuasaan Kehakiman tepatnya pada Pasal 5 dengan tegas menyebutkan bahwa hakim wajib menggali nilai-nilai yang hidup dalam masyarakat (the living law atau local wisdom). Dengan demikian, pada hakikatnya hakim harus atau wajib menerapkan pendekatan atau konsep keadilan restoratif (restorative justice) dalam menyelesaikan perkara karena pendekatan atau konsep keadilan restoratif (restorative justice) sesuai dengan jiwa bangsa Indonesia yakni Pancasila, sesuai dengan nilai-nilai hukum adat dan sesuai pula dengan nilai-nilai agama.

Perlu pula dikemukakan bahwa konsep keadilan restoratif (restorative justice) tidak hanya dapat diterapkan kepada Mahkamah Agung (MA). Dalam proses peradilan pidana pada umumnya dan proses peradilan pidana di Indonesia pada khususnya, terdapat beberapa tahapan atau proses yang harus dilalui bagi para pencari keadilan baik di tingkat penyelidikan, penyidikan,penuntutan, pemeriksaan di pengadilan hingga tahap penjatuhan putusan hakim. ${ }^{20}$ Bahkan pada tahapan dimana para pencari keadilan melakukan upaya hukum (baik upaya hukum biasa maupun upaya hukum luar biasa). Dengan demikian, penulis menilai bahwa sudah seyogianya pengadopsian dan penerapan konsep keadilan restoratif (restorative justice) dilakukan diberbagai tingkatan atau proses peradilan sebagaimana dikemukakan diatas.

Berdasarkan penjelasan diatas, penulis juga menyimpulkan bahwa konsep atau pendekatan keadilan restoratif (restorative justice) harus dilaksanakan secara

20 Melihat bahwa titik sentral pada Sistem Peradilan Pidana Terpadu saat ini adalah hakim, hakimlah yang paling banyak dikecam oleh masyarakat apabila putusan yang dibuatnya dinilai tidak mencerminkan rasa keadilan. 
terintegrasi.Hal ini menjadi penting mengingat apabila salah satu dari komponan tersebut tidak menerapkan konsep atau pendekatan keadilan restoratif (restorative justice) maka putusan yang restoratif tidak mungkin dapat terlaksana. Misalnya, kepolisian dan kejaksaan telah menganut konsep keadilan restoratif namun hakim masih menganut pola pikir yang legistis, dalam kasus seperti ini hakim akan menjatuhkan putusan yang sangat normatif sehingga lembaga pemasyarakatanpun tidak bisa menerapkan konsep keadilan restoratif. Oleh karenanya, pendekatan atau konsep keadilan restoratif (restorative justice) harus dilaksanakan secara terintegrasi antara komponen yang satu dengan komponen yang lainnya. Sebaliknya, apabila satu komponen tidak menjalankan pendekatan atau konsep keadilan restoratif (restorative justice) maka pendekatan atau konsep keadilan restoratif (restorative justice) itu sendiri tidak akan terealisasi dengan baik.

\section{PENUTUP.}

\section{A. Kesimpulan.}

1. Implementasi konsep keadilan restoratif (restorative justice) dalam sistem peradilan pidana terpadu di Indonesia belum dilaksanakan secara terintegrasi. Hal ini salah satunya disebabkan karena sub-sub sistem peradilan pidana (kepolisian, kejaksan, kehakiman, lembaga pemasyarakatan) di Indonesia belum mengerti secara utuh apa sebenarnya yang dimaksud dengan konsep keadilan restoratif.

2. Lembaga peradilan di Indonesia belum menerapkan atau mengimplementasikan konsep keadilan restoratif secara keseluruhan. Hal ini dibuktikan bahwa jika dilihat dari "rangkaian perkembangan konsep keadilan restoratif" maka pelaksanaan konsep keadilan restoratif di Indonesia belum dilaksanakan atau masuk dalam kategori "bisa restoratif' (artinya belum menggunakan konsep keadilan restoratif) atau setidaknya sampai dengan tahap "restoratif sebagian". Sistem peradilan pidana di Indonesia masih berada pada tahap "bisa restoratif" karena keterlibatan korban bukanlah perhatian utama, keputusan dibuat oleh pihak yang tidak secara langsung terkena dampak, tidak ada pilihan untuk 
dialog di antara mereka yang terkena dampak langsung, fokusnya adalah pada aturan atau hukum yang dilanggar dan konsekuensi dari perbuatannya (pertanggungjawaban pasif), tidak berfokus pada upaya untuk memulihkan kerusakan atau kerugian yang dialami. Selain itu, penulis berpandangan bahwa sistem peradilan pidana di Indonesia setidaknya masuk pada tahap "restoratif sebagian" karena para pemangku kepentingan merupakan kunci untuk memberikan informasi sampai tingkat yang terbatas, beberapa para pemangku kepentingan memiliki beberapa keputusan atau masukan akan tetapi, keputusan akhir tetap dibuat atau disetujui oleh sistem formal. Dalam tahap"restoratif sebagian", terdapat kesempatan terbatas untuk dialog antara beberapa para pemangku kepentingan, perhatian utama adalah dengan membayar untuk bahaya dan kebutuhan tetapi fokus utama adalah aturan atau hukum yang dilanggar dan segala konsekuensi yang muncul dan beberapa upaya dilakukan untuk memulihkan sebagian kerugian yang sangat nyata. Sering kali, bahaya dan upaya untuk memulihkan diberikan kepada orang lain selain mereka yang secara langsung terkena dampak.

\section{B. Saran.}

1. Strategi pemberantasan tindak pidana di Indonesia memasuki abad modern ini harus mengalami perubahan paradigma yakni penanganan suatu tindak pidana tidak dapat dilakukan hanya dengan cara-cara tradisional misalnya hanya dengan memasukan pelaku tindak pidana kedalam penjara melainkan menggunakan sebuah tahapan baru yaitu tahapan penguatan sistem pencegahan (preventive measures) yaitu dengan lebih menitik beratkan atau memprioritaskan kepada pemulihan dampak kejahatan dengan tetap memperhatikan tujuan yang ingin dicapai oleh hukum pidana yaitu efek jera bagi pelaku dan mencegah orang lain untuk melakukan tindak pidana yang salah satunya dapat diwujudkan dengan konsep atau pendekatan keadilan restoratif (restorative justice).

2. Mahkamah Agung (MA) sebagai lembaga negara yang melaksanakan kekuasaan kehakiman dan sebagai puncak peradilan sudah seyogianya 
mengadopsi atau menganut dan menerapkan pendekatan atau konsep keadilan restoratif (restorative justice). Dengan cara ini diharapkan peradilan yang ada dibawahnya (Pengadilan Negeri maupun Pengadilan Tinggi) akan mengadopsi, menganut dan menerapkan konsep keadilan restoratif (restorative justice).

3. Sudah seyogianya pengadopsian dan penerapan konsep keadilan restoratif (restorative justice) dilakukan diberbagai tingkatan atau proses peradilan (tingkat penyelidikan, penyidikan, penuntutan, pemeriksaan di pengadilan) dan juga dilaksanakan oleh Advokat dan Komisi Yudisial.

4. Konsep atau pendekatan keadilan restoratif (restorative justice) harus dilaksanakan oleh seluruh sub sistem peradilan pidana secara integral, konsisten dan berkelanjutan sehingga tercipta integrated criminal justice system yang restoratif.

5. Melakukan sosialisasi di berbagai instansi penegak hukum mengenai konsep atau pendekatan keadilan restoratif dan implementasinya dalam praktek.

6. Hakim dalam menjatuhkan putusan seyogianya menerapkan konsep keadilan restoratif (restorative justice) secara konsisten. 


\section{DAFTAR PUSTAKA}

A. Buku.

Bambang Sutiyoso, Penyelesaian Sengketa Bisnis, Solusi Dan Antisipasi Bagi Peminat Bisnis Dalam Menghadapi Sengketa Kini dan Mendatang, Yogyakarta, Citra Media, 2006.

Bryan A. Garner, Black's Law Dictionary, Edisi Delapan, West Publishing CO, Amerika Serikat, 2004.

Dewi DS dan A. Syukur Fatahilah, Mediasi Penal: Penerapan Restorative Justice di Pengadilan Anak Indonesia, Depok, Indie Publishing, 2011.

Geoge pavlich, Towards an Ethics of Restorative Justice, dalam Restorative Justice and The Law, ed Walgrave, L., WWillan Publishing, Oregon, 2002.

Gordon Bazemore dan Mara Schiff, Juvenile Justice Reform and Restorative justice: Building Theory and Policy from Practice, Willan Publishing, Oregon, 2005.

Heru Susetyo dan Tim Kerja Pengkajian Hukum, Laporan Tim Pengkajian Hukum Tentang Sistem Pembinaan Narapidana Berdasarkan Prinsip Restorative Justice, Badan Pembinaan Hukum Nasional Kementerian Hukum Dan Hak Asasi Manusia Republik Indonesia Tahun 2012.

Howard Zehr, Changing Lenses: A New Focus for Crime and Justice, Scottdale, Pennsylvania; Waterloo, Ontario: Herald Press, 1990.

Joni Emirzon, Alternatif Penyelesaian Sengketa di Luar Pengadilan, Jakarta, PT Gramedia Pustaka Utama, 2001.

Muladi, Kapita Selekta Sistem Peradilan Pidana, Semarang: Badan Penerbit UNDIP, 1996.

Rufinus Hotmaulana Hutauruk, Penanggulangan Kejahatan Korporasi Melalui Pendekatan Restorative Justice Suatu Terobosan Hukum, Sinar Grafika, 2013.

Satjipto Rahardjo, Sisi-Sisi Lain dari Hukum di Indonesia, Jakarta, Kompas, 2003.

Sudikno Mertokusumo, Mengenal Hukum: Suatu Pengantar, Universitas Atmajaya, Yogyakarta 2010.

Tony marshall, Keadilan restoratif: Tinjauan di London, Home Office Research Development and Statistics Directorate, 1999. Jakarta, Office Home Penelitian Pengembangan dan Statistik Direktorat, 1999. 


\section{B. Peraturan Perundang-Undangan.}

Undang-Undang Dasar 1945

Kitab Undang-Undang Hukum Pidana (KUHAP)

Undang-Undang Nomor 14 Tahun 1985 tentang Mahkamah Agung Jo.UndangUndang Nomor 3 Tahun 2009 tentang Mahkamah Agung

Peraturan Kepala Kepolisian Negara Republik Indonesia Nomor 7 tahun 2008 tentang Pedoman dasar strategi dan Implementasi Pemolisian masyarakat dalam penyelenggaraan Tugas Polri.

C. Jurnal, Makalah, Internet, Dan Lain-lain.

Eva Achjani Zulfa, Keadilan Restoratif Dan Revitalisasi Lembaga Adat Di Indonesia, Jurnal Kriminologi Indonesia Vol. 6 No.II Agustus 2010 : 182 203.

Kristian, Penyelesaian Perkara Pidana Dengan Konsep atau Pendekatan Keadilan Restoratif (Restorative Justice) Khususnya Secara Mediasi (Mediasi Penal) Dalam Sistem Hukum Pidana Indonesia Ditinjau Dari Filsafat Hukum, Jurnal Hukum Mimbar Justitia Vol. VI No. 02 Edisi JuliDesember 2014.

, Penerapan Keadilan Restoratif (Restorative Justice) Ditinjau Dari Teori Keadilan, Teori Kemanfaatan dan Teori Negara Hukum (Khususnya Negara Hukum Pancasila) Dalam Rangka Penyelesaian Perkara Pidana di Indonesia, Tesis, Universitas Katolik Parahyangan, 2014.

R. Budi Wicaksono, Community Policing dan Restorative Justice Sebagai Paradigma Baru dalam Resolusi Konflik, Tesis Fakultas Ilmu Sosial dan Ilmu Polilik Departemen Kriminologi Program Pasca Sarjana Universitas Indonesia. Depok, 2008. 